\title{
In silico and in vitro cytotoxicity profile of hydroalcoholic extract/ fraction(s) of Pachygone ovata
}

\author{
Jeswiny Rodrigues ${ }^{1}$, Kiran Kumar Hullatti ${ }^{1 *}$, Pukar Khanal ${ }^{2}$ \\ ${ }^{1}$ Department of Pharmacognosy and Phytochemistry, KLE College of Pharmacy, Belagavi, KLE Academy of Higher Education and Research (KAHER), \\ Belagavi-590010, India \\ ${ }^{2}$ Department of Pharmacology and Toxicology, KLE College of Pharmacy, Belagavi, KLE Academy of Higher Education and Research (KAHER), \\ Belagavi-590010, India
}

\section{ARTICLE INFO \\ Received on: 15/02/2020 \\ Accepted on: 16/04/2020 \\ Available online: 06/05/2020}

\section{Key words:}

Bisbenzylisoquinoline, brine

shrimp, Menispermaceae,

MTT, topoisomerase.

\begin{abstract}
Medicinal plants have been used in the past for the treatment of diseases and continue to be an important reservoir for the development of new drugs. With the increasing burden of cancer globally, there is a need to find newer anticancer agents. The process of identification and evaluation of cytotoxic molecules from plants can be achieved conveniently by using simple yet reliable screening models and combining with in silico techniques. Pachygone ovata, least explored plant from Menispermaceae family, is known to be rich in alkaloids. This study aimed to identify the cytotoxic constituents from Pachygone ovata through bioactivity-guided fractionation using Brine shrimp lethality bioassay as a screening model. The active fraction in this assay was evaluated for its in vitro cytotoxic activity on human tumor cell lines. Some reported alkaloids were studied for their binding affinities with topoisomerase II by molecular docking. The study revealed the cytotoxic constituents from P. ovata. The study also revealed alkaloids with higher binding affinity with topoisomerase II, and the scope for further use leads to the development of new drugs.
\end{abstract}

\section{INTRODUCTION}

In the past, medicinal herbs were used to treat even the most complex conditions related to cancer such as inflammation, swellings, growths, and warts. Over 2,000 plant species of medicinal value have been recorded and are used for therapeutic purpose in different forms (Biljana, 2012). Cancer begins as a result of altered cell function, due to genetic and epigenetic changes within the cell leading to genetic instability (Anna, 2019). At present, cancer is the second largest cause of death worldwide. According to the WHO, cancer accounted for an estimated 9.6 million deaths in 2018 and continues to grow globally (WHO, 2020). The complication in treatment arises due to the uncontrolled proliferation of cells and invasion into other tissues, and thus, ineffective treatment and toxic side effects associated with chemotherapy necessitate the discovery of alternative treatment options (Chidambaram et al., 2011).

${ }^{*}$ Corresponding Author

Kiran Kumar Hullatti, Department of Pharmacognosy, KLE College of Pharmacy, Belagavi, India.E-mail:kkhullatti@gmail.com
Medicinal plants still prove to be an important resource in the development of new drugs. Currently, a number of drugs derived from plants have been approved for clinical use, including cancer therapy (Cragg and Newman, 2005). Extensive research findings suggest that phytochemicals and their derived analogs are reported to inhibit the progression of cancerous cells through various mechanisms and have the most promising alternative for the treatment of cancer (Ana et al., 2018). The Indian system of medicine offers a number of plants that possess cytotoxic activities (Petrovska, 2012). Pachygone ovata (Poir.) Miers ex Hook. f. Et Thoms belonging to the family Menispermaceae is a deciduous woody shrub that can climb up to $15 \mathrm{~m}$ or more. The dried fruits of $P$. ovata have been used traditionally to repel insects and as fish poison (Shirin et al., 2014). It is one of the least explored plants, which is rich in active phytoconstituents, especially alkaloids. Different benzyl-isoquinoline-derived alkaloids have been reported from $P$. ovata stems, leaves, and roots (El-Kawi et al., 1984). Alkaloids have been well known for their inhibitory action on a wide range of tumors through different mechanisms (Lu et al., 2012). 
The brine shrimp lethality (BSL) assay is reported to be an effective screening model for potential cytotoxic constituents and has led to the identification of many cytotoxic compounds through bioactivity-guided approach (Meyer et al., 2005). Computational tools, in recent years, are being employed to study the modes of interaction, bioavailability, and toxicities of the possible lead compound with the target protein (Rosales-Hernandez et al., 2009). The inhibition of topoisomerase enzymes is one of the many modes, through which drugs may exert their effects on cancer cells. Important cellular functions such as replication, recombination, transcription, and DNA repair are governed by the activities of topoisomerase I and II (Kumar et al., 2013). The inhibition of such enzymes has been the target in anticancer drug research since recent years (Sivakumar et al., 2010). The use of simple and reliable screening models combined with modern in silico techniques can make the process of identification of bioactive constituents from plants effective and convenient (Khanal et al. 2019a, 2019b). Thus, this study was carried out to identify the potential cytotoxic constituents from $P$. ovata through the bioactivity-guided approach and molecular docking, which could be promising in the development of new drugs. The phytoconstituents used for docking i.e., coreximine, isoboldine, liriodenine, norjuziphine, pachygonine, reticuline, nortrilobine, and trilobine including standard etoposide are shown in Figure 1.

\section{MATERIALS AND METHODS}

\section{Collection, authentication, extraction, and fractionation of plant}

The wild-grown whole plant of $P$. ovata was collected in the month of July-September, from areas of Tirupati, Eastern Ghats, Andhra Pradesh, authenticated at Sri Venkateswara
University, Tirupati, Andhra Pradesh, and the herbarium of the same was deposited with voucher number 0827 for future reference. The dried plant material was extracted by cold maceration using $70 \% \mathrm{v} / \mathrm{v}$ ethanol for 24 hours. After filtration, the marc was dried and further extracted by Soxhlet extraction. The macerate and percolate were then combined and concentrated using a rotary evaporator (IKA-RV Digital) to obtain the final extract. The fractionation of extract was carried as explained by Cos et al. (2006) to obtain methanol, petroleum ether, dichloromethane, and aqueous fractions.

\section{Cell culture}

MCF-7 (human, breast cancer), HT-29 (human, colon cancer), A-549 (human, small-cell lung carcinoma), HepG-2 (human, hepatic cancer), and L-6 (rat, normal skeletal muscle) cell lines were purchased from National Centre for Cell Science, Pune, India. The cells were cultured in $25 \mathrm{~cm}^{2}$ culture flasks with Dulbecco's modified eagle medium (DMEM) supplemented with $10 \%$ inactivated fetal bovine serum (FBS), penicillin $(100 \mathrm{IU} / \mathrm{ml})$, streptomycin $(100 \mathrm{mg} / \mathrm{ml})$, and amphotericin B $(5 \mathrm{mg} / \mathrm{ml})$ in a humidified atmosphere of $5 \% \mathrm{CO}_{2}$ at $37^{\circ} \mathrm{C}$ until confluent. The cells were dissociated with trypsin phosphate versene glucose solution $0.2 \%$ trypsin, $0.02 \%$ Ethylenediaminetetraacetic acid (EDTA) and $0.05 \%$ glucose in Phosphate-buffered saline (PBS)).

\section{Evaluation of cytotoxicity}

BSL bioassay

The brine shrimp (Artemia salina Leach.) eggs were purchased from a local vendor. The procedure was carried out according to the procedure reported (Mc Laughlin and Roggers, a

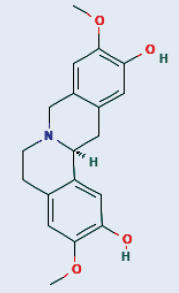

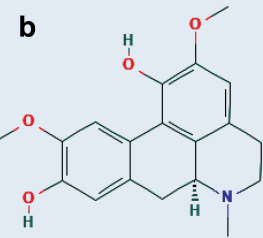

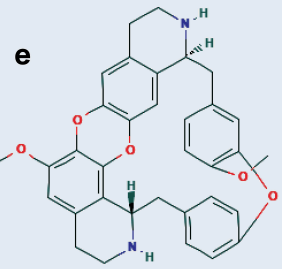

h

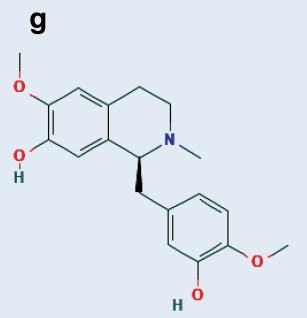

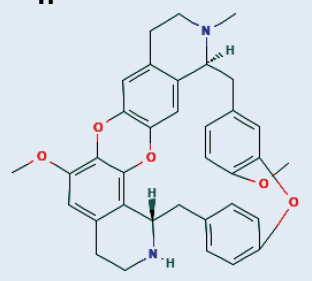

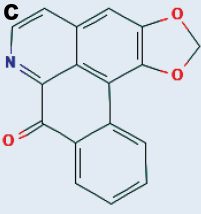

$\mathbf{f}$

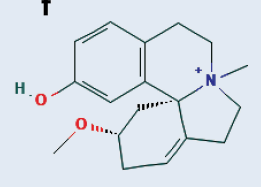

i

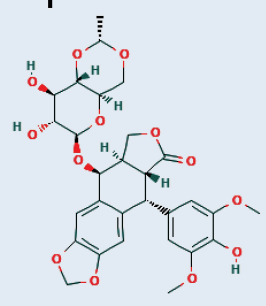

Figure 1. Structure of (a) coreximine, (b) isoboldine, (c) liriodenine, (d)norjuziphine, (e) nortrilobine, (f) pachygonine, (g) reticuline, (h) trilobine and (i) etoposide. 
1998) with modifications. Briefly, the stock solution of extracts/ fractions was prepared in $1 \%$ DMSO and serially diluted using sea water to obtain solutions of $10,50,100,500$, and $1,000 \mu \mathrm{g} / \mathrm{ml}$. Ten nauplii were added to $5 \mathrm{ml}$ of each test solution. Control tubes contained equal volumes of distilled water. The assay was carried out in triplicate for each concentration. The tubes were kept under illumination, and the number of survivors was counted after 24 hours and the percentage of mortality was calculated. $\mathrm{LC}_{50}$ values were calculated by Probit analysis using SPSS-10.0.5 software (Armonk, NY).

\section{3-(4,5-Dimethylthiazol-2-Yl)-2,5-Diphenyltetrazolium Bromide (MTT) assay for cytotoxicity}

The active fractions from BSL bioassay were screened for cytotoxicity by the 3-(4,5-dimethylthiazol-2-yl)2,5-diphenyltetrazolium bromide (MTT) assay as previously described (Lombardi et al., 2017). Cells were collected by trypsinization, and the cell count was adjusted to $1.0 \times 10^{5}$ cells/ $\mathrm{ml}$ per well using DMEM medium containing 10\% FBS. After 24 hours of incubation at $37^{\circ} \mathrm{C}$ in $5 \% \mathrm{CO}_{2}$ atmosphere, $100 \mu \mathrm{l}$ of the various concentrations of the sample were added to the wells and incubated. After 48 hours, $20 \mu 1$ of MTT was added to each well and incubated for 4 hours. The supernatant was discarded, and DMSO was added to each well. The absorbance was measured using a microplate reader at a wavelength of $540 \mathrm{~nm}$. The percentage growth inhibition and $\mathrm{IC}_{50}$ values were calculated.

Percentage growth inhibition $(\%)=\left[\frac{\text { Absorbance of test }}{\text { Absorbance of control }}\right] \times 100$

where $\mathrm{A}(\mathrm{control})=\mathrm{Absorbance}$ of control, $\mathrm{A}($ sample $)=$ Absorbance of sample

\section{Molecular docking}

The selected ligand molecules, i.e., coreximine, isoboldine, norjuziphine, nortrilobine, trilobine, liriodenine, pachygonine, and reticuline were retrieved from the PubChem database ( .sdf format), converted into .pdb using Discovery Studio 2017 and minimized using mmff 94 force field and conjugate gradients as an optimization algorithm. After minimization, the pose with the least energy was chosen for docking. Topoisomerase II (PDB: 4GHF) was retrieved from the RCSB database and used as a template for query sequence for Accession number: P11388.3 for the homology modeling by adding the missing amino acid using Modeller 9.10. The protein molecule was made free from heteromolecules using Discovery Studio 2017 to avoid docking interference and saved in .pdb format, and the docking was carried by using AutoDock 4.0 under Lamarckian GA 4.2. The protein was viewed in Ramachandran plot to assess the distributed amino acid residues using Procheck (https://servicesn.mbi.ucla.edu/ PROCHECK/). After docking, the pose scoring minimum binding energy was chosen to visualize the ligand-protein interaction using Discovery Studio 2017. All the docking results were compared with the known topoisomerase II inhibitor, i.e., etoposide.

\section{Statistical analysis}

Data were expressed as mean \pm SD using GraphPad Prism version 5.0. The IC50 was calculated using a linear regression model.

\section{RESULTS}

\section{BSL bioassay}

The hydroalcoholic extract of $P$. ovata displayed high toxicity toward shrimp nauplii with $\mathrm{LC}_{50}: 58.411 \pm 1.33 \mu \mathrm{g} /$ $\mathrm{ml}$. The fractions showed toxicity toward shrimp nauplii in a concentration-dependent manner and are shown in Figure 2. Fraction 3 showed the highest percentage mortality of nauplii and $\mathrm{LC}_{50}: 30.47 \pm 1.66 \mu \mathrm{g} / \mathrm{ml}$. Fraction 4 showed the least percentage mortality in this assay. The $\mathrm{LC}_{50}$ of hydroalcoholic extract/ fraction is shown in Table 1

\section{MTT assay}

Alkaloid-rich Fraction 3 of $P$. ovata displayed a notable cytotoxicity in the cell lines. The cytotoxicity increased with increasing concentration and is shown in Figure 3. The

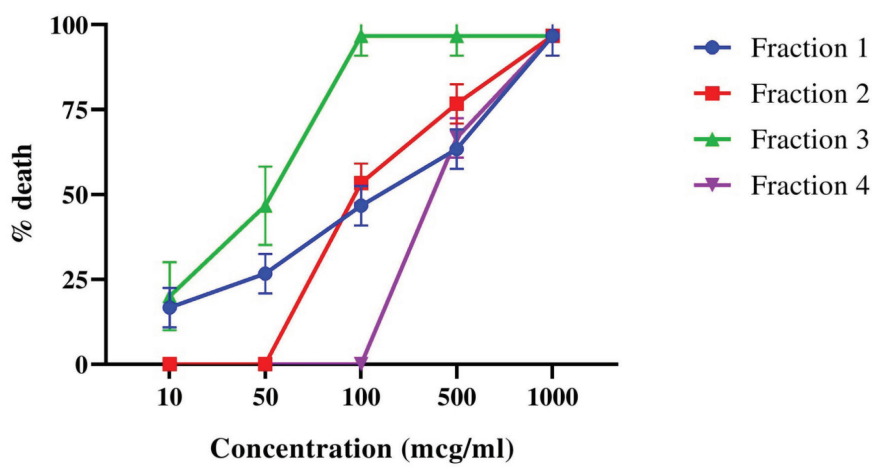

Figure 2. Brine shrimp mortality by various fractions of $P$. ovata.

Table 1. Evaluation of $P$. ovata extract and fractions in the BSL bioassay

\begin{tabular}{lc}
\hline Test agent & $\mathbf{L C}_{\mathbf{5 0}}(\boldsymbol{\mu g} / \mathbf{m l})$ \\
\hline P. ovata alcoholic extract & $58.411 \pm 3.33$ \\
Fraction 1 & $261.57 \pm 2.14$ \\
Fraction 2 & $163.92 \pm 3.73$ \\
Fraction 3 & $30.47 \pm 1.66$ \\
Fraction 4 & $429.94 \pm 3.27$ \\
\hline
\end{tabular}

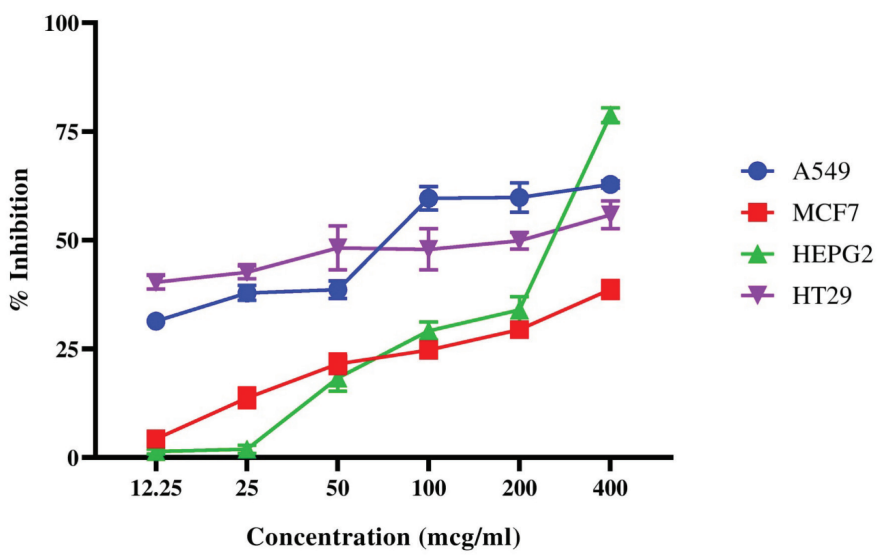

Figure 3. Cell growth inhibition of Fraction 3 of $P$. ovata in different cell lines. 
most cytotoxicity was observed towards the A-549 cell line compared to the others displaying $\mathrm{IC}_{50}=84.76 \pm 1.47 \mu \mathrm{g} / \mathrm{ml}$. The least cytotoxicity was noted in the MCF-7 cell line, whereas no cytotoxicity was observed in the normal cell line L6. Table 2 shows the $\mathrm{IC}_{50}$ of a fraction rich in alkaloids in multiple cell lines.

\section{Molecular docking}

In the homology modeled protein, the residues in most favored, allowed, and generously allowed regions were $81.5 \%$, $14.2 \%$, and $2.7 \%$, respectively (Figure 4 ). The docking study predicted trilobine to possess the highest binding affinity $(-11.2$

Table 2. Evaluation of cytotoxicity using the MTT assay.

\begin{tabular}{lcccccc}
\hline \multirow{2}{*}{ Test agent } & \multicolumn{5}{c}{ IC $_{\mathbf{5 0}}(\boldsymbol{\mu g} / \mathbf{m l})$} \\
\cline { 2 - 7 } & $\mathbf{A - 5 4 9}$ & MCF-7 & HT-29 & HepG2 & L-6 \\
\hline Fraction rich in alkaloids & $84.76 \pm 1.47$ & $333.7 \pm 4.23$ & $91.12 \pm 2.17$ & $625.10 \pm 2.73$ & $>1000$ \\
Paclitaxel & $7.43 \pm 0.33$ & $10.52 \pm$ & $12.67 \pm 1.29$ & $15.81 \pm 2.26$ & $323 \pm 2.73$ \\
\hline
\end{tabular}

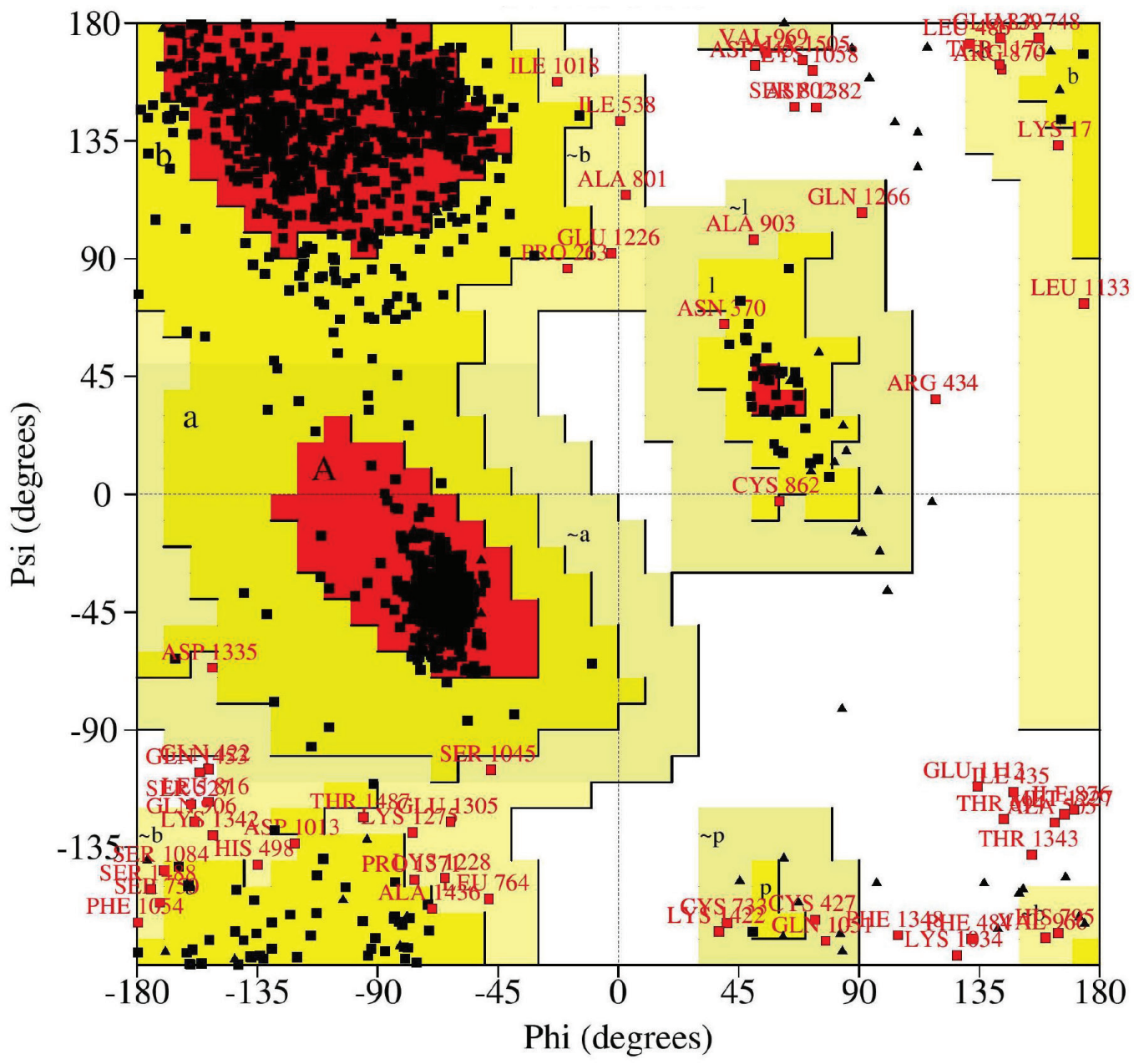

Plot statistics

$\begin{array}{lrc}\text { Residues in most favoured regions [A,B,L] } & 1118 & 81.5 \% \\ \text { Residues in additional allowed regions [a,b,l,p] } & 195 & 14.2 \% \\ \text { Residues in generously allowed regions [ } \sim \mathrm{a}, \sim \mathrm{b}, \sim 1, \sim \mathrm{p}] & 37 & 2.7 \% \\ \text { Residues in disallowed regions } & 21 & 1.5 \% \\ & --- & -000.0 \\ \text { Number of non-glycine and non-proline residues } & 1371 & 100 . \\ \text { Number of end-residues (excl. Gly and Pro) } & 2 & \\ \text { Number of glycine residues (shown as triangles) } & 84 \\ \text { Number of proline residues } & 74 & \\ & --- & \end{array}$

Figure 4. Ramachandran plot of homology modeled topoisomerase II. 
$\mathrm{kcal} / \mathrm{mol}$ ) compared to others. However, no hydrogen bond interactions were found with the amino acids of topoisomerase II. Although reticuline was predicted to have binding energy -7.2 $\mathrm{kcal} / \mathrm{mol}$, it was found to be interactive with two amino acids, i.e., GLU1494 and MET1500. Table 3 shows the binding affinity of each ligand molecule with topoisomerase II. Figure 5 shows the interaction of liriodenine, pachygonine, norjuziphine, trilobine, nortrilobin, coreximine, isoboldine, reticuline, and etoposide with topoisomerase II.

\section{DISCUSSION}

The BSL bioassay, a general test for screening bioactive compounds, was used in this study to identify the potential cytotoxic constituents in P. ovata. According to several reports, the BSL test predicts cytotoxicity and has been successfully

Table 3. Binding affinity of ligand with Topoisomerase II.

\begin{tabular}{lccl}
\hline Ligand & $\begin{array}{c}\text { Binding affinity } \\
(\mathbf{k c a l} / \mathbf{m o l})\end{array}$ & $\begin{array}{c}\text { Number of hydrogen } \\
\text { bonds }\end{array}$ & \multicolumn{1}{c}{$\begin{array}{c}\text { Hydrogen bond } \\
\text { residues }\end{array}$} \\
\hline Liriodenine & -9.3 & - & - \\
Norjuziphine & -7.6 & 1 & MET1500 \\
Pachygonine & -8.4 & 1 & LYS512 \\
Reticuline & -7.2 & 2 & GLU1494, MET1500 \\
Trilobine & -11.2 & - & - \\
Coreximine & -4.58 & 2 & GLY 474, LYS480 \\
Isoboldine & -4.94 & 1 & TYR 481 \\
Nortrilobine & -4.42 & - & - \\
Etoposide & -9.2 & 3 & HIS605, ASN508, \\
& & & GLN517 \\
\hline
\end{tabular}

${ }^{\mathrm{a} K n o w n ~ m o l e c u l e ~ a s ~ t o p o i s o m e r a s e ~ i n h i b i t o r . ~}$ utilized in the bioassay-guided fractionation of active cytotoxic and antitumor agents (Arullappan et al., 2015; Zhanga et al., 2015). The reports suggest a significant correlation between the brine shrimp assay and in vitro inhibition of human tumor cell lines (Anderson et al., 1991).

In this study, the fraction rich in alkaloids showed the highest mortality of the brine shrimp nauplii compared to the other three fractions, $\mathrm{LC}_{50}=30.47 \pm 1.66 \mu \mathrm{g} / \mathrm{ml}$, which is considered as cytotoxic as explained by Pimentel Montanher et al. (2002). Hence, the alkaloid fraction was further evaluated for its in vitro cytotoxicity using multiple human tumor cell lines using the MTT assay. Although there have not been notable reports regarding the cytotoxicity of $P$. ovata, there are, however, studies reporting the antioxidant (Amalarasi and Jothi, 2019) and anti-inflammatory (Marahel and Sharanaiah, 2016) activities of $P$. ovata extracts, both of which have a close association with the pathogenesis of cancer (Yoshikawa and Naito, 2002; Rayburn et al., 2009). In accordance, a noteworthy cytotoxic effect of the alkaloid rich fraction was observed in this study. The highest cytotoxicity $\left(\mathrm{IC}_{50}=84.76 \pm\right.$ $1.47 \mu \mathrm{g} / \mathrm{ml}$ ) was noted against A-549 (human lung cancer) cell line. Moreover, worth noticing was that the fraction was relatively nontoxic toward the L-6 cell line indicating biocompatibility with the normal cell line. The preliminary screening of hydroalcoholic extract/fraction (s) in BSL bioassay was found to be effective in identifying potentially toxic fractions containing alkaloids, which further displayed significant cytotoxicity in vitro, and thus confirming its productive use in our study.

$P$. ovata, which is a member of the Menispermaceae family, is reported to constitute benzylisoquinoline alkaloids (El-Kawi et al., 1984). This study also identifies alkaloids from
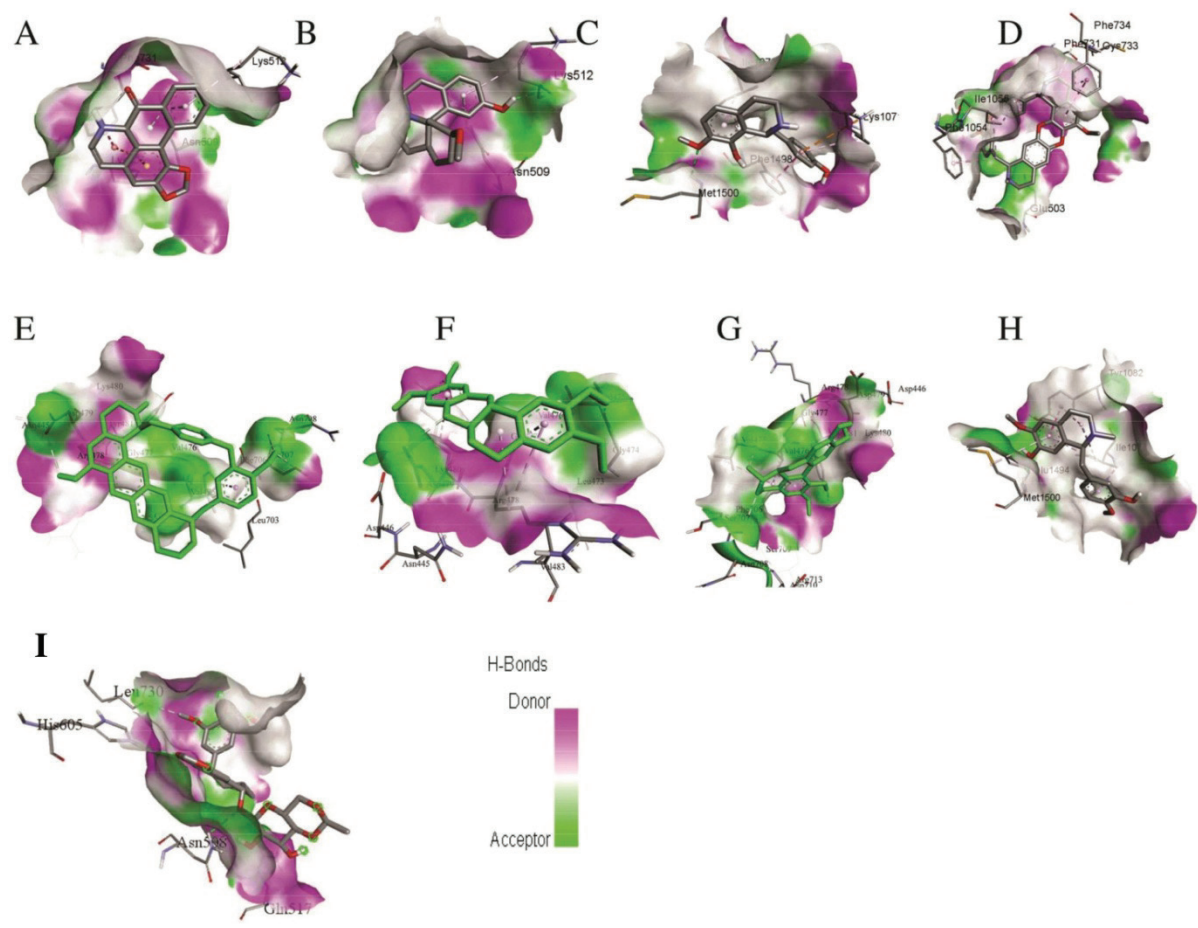

Figure 5. Interaction of (a) liriodenine, (b) pachygonine, (c) norjuziphine, (d) trilobine, (e) nortrilobin, (f) coreximine, (g) isoboldine, (h) reticuline, and (i) etoposide with topoisomerase II. 
P. ovata which could be a relatively promising group of natural products as a source of new anticancer agents. Hence, in silico docking studies were carried out on previously reported alkaloids (liriodenine, trilobine, pachygonine, coreximine, reticuline, isoboldine, norjuziphine, and nortrilobine) against Topoisomerase II. Topoisomerase II is an enzyme involved in DNA replication. Topoisomerase II is radically upregulated in cancer cells due to rapid cell division and growth (Nainwal et al., 2014). Topo II is a potential target in the designing of newer anticancer agents (Heck et al., 1986). In this study, alkaloids from $P$. ovata were found to interact with topoisomerase II, suggesting their involvement in cancer management.

It was reported that the stability of the ligand-protein complex depends on the binding energy as well as hydrogen bond interactions. In this study, although trilobine was found to have the highest binding affinity with topoisomerase II, the complex may not be stable since it could not form any hydrogen bond interactions with any amino acid of protein molecules. Although reticuline was predicted to have binding energy $-7.2 \mathrm{kcal} / \mathrm{mol}$, it was found to be interactive with a protein molecule. Reticuline has previously shown in vitro cytotoxic activity in human tumor cell lines such as P-388, KB16, and A549 (Chen et al., 1997; Suresh et al., 2012), demonstrating its future scope in cancer research.

Further, cancer is a polygenic condition, in which multiple proteins are involved in its pathogenesis (Bredberg, 2011). The fraction rich in alkaloids could modulate the multiple proteins and pathways which can be accessed through the gene-set enrichment analysis (Khanal and Patil, 2019; Khanal and Patil, 2020) and network pharmacology (Khanal et al., 2019c) which is also a future scope of the present study.

\section{CONCLUSION}

This study revealed potential cytotoxic alkaloids from $P$. ovata. Further, the docking study predicted the binding ability of alkaloids from $P$. ovata with topoisomerase II; however, further investigations need to be carried out to validate the findings and the use of alkaloids from $P$. ovata leads to cancer treatment.

\section{ACKNOWLEDGMENT}

The authors are grateful to the Principal, KLE College of Pharmacy, Belagavi, and KLE's Dr. Prabhakar Kore Basic Science Research Centre, Belagavi, for providing necessary facilities for carrying out the work.

\section{FINANCIAL SUPPORT}

None.

\section{CONFLICT OF INTEREST} interests

Authors declare that they do not have any competing

\section{REFERENCES}

Amalarasi LE, Jothi GJ. Phytochemical profiling and antioxidant activity of the extracts of Pachygone ovata (Poir.) Miers ex Hook.f. \& Thomson. J Pharmacogn Phytochem, 2019; 8(3):204-9.

Ana ML, Seca ID, Diana CG, Pinto A. Plant secondary metabolites as anticancer agents: successes in clinical trials and therapeutic application. Int J Mol Sci, 2018; 19:263-64.
Anderson JE, Goetz CM, Mclaughlin JL, Suffness M. A blind comparison of simple benchtop bioassay and human tumour cell cytotoxicities as antitumor prescreens. Phytochem Analysis, 1991;2:107-11.

Anna ML, Marcin R, Sławomir R, Tomasz L, Barbara L. Environmental risk factors for cancer - review paper. Ann Agric Environ Med, 2019; 26(1):1-7.

Arullappan S, Rajamanickam P, Thevar N, Narayanasamy D, Yee Yee H, Kaur P. Cytotoxic effect and antioxidant activity of bioassay guided fractions from Solanum nigrum extracts. Trop J Pharm Res, 2015; 14(7):1199-202.

Biljana BP. Historical review of medicinal plants' usage. Pharmacogn Rev, 2012; 6(11):1-5.

Bredberg A. Cancer: more of polygenic disease and less of multiple mutations? A quantitative viewpoint. Cancer. 2011; 117(3):440-5. doi:10.1002/cncr.25440

Chen IS, Chen JJ, Duh CY, Tsai IL, Chang CT. New aporphine alkaloids and cytotoxic constituents of Hernandia nymphaeifolia. Planta Med, 1997; 63(2):154-7.

Chidambaram M, Manavalan R, Kathiresan K. Nanotherapeutics to overcome conventional cancer chemotherapy limitations. J Pharm Pharm Sci, 2011; 14(1):67-77.

Cos P, Vlietinck AJ, Berghe DV, Maes L. Anti-infective potential of natural products: how to develop a stronger in vitro proof-of-concept. J Ethnopharmacol, 2006; 106:290-302.

Cragg GM, Newman DJ. Plants as a source of anti-cancer agents. J Ethnopharmacol, 2005; 100:72-9.

El-Kawi MA, Slatkinp DJ, Schiff L, Dasgupta S, Chattopadhyay SK, Ray AB. Additional alkaloids of Pachygone ovata. J Nat Prod, 1984; 47(3):459-64

Heck MM, Earnshaw WC. Topoisomerase II: a specific marker for cell proliferation. J Cell Biol. 1986; 103:2569-81.

Khanal P, Magadum P, Patil BM, Hullatti KK. In silico docking study of Limonoids from Azadirachta indica with pfpk5: a novel target for Plasmodium falciparum. Indian J Pharm Sci, 2019b; 81(2):326-32.

Khanal P, Patil BM, Hullatti KK. In silico antidiabetic screening of borapetoside $\mathrm{C}$, cordifolioside A and magnoflorine. Indian J Pharm Sci, 2019a; 81(3):550-5.

Khanal P, Patil BM, Mandar BK, Dey YN, Duyu T. Network pharmacology-based assessment to elucidate the molecular mechanism of anti-diabetic action of Tinospora cordifolia. Clin Phytosci, 2019c; 5:35.

Khanal P, Patil BM. Gene set enrichment analysis of alphaglucosidase inhibitors from Ficus benghalensis. Asian Pac J Trop Biomed, 2019;9(6):263-70.

Khanal P, Patil BM. $\alpha$-Glucosidase inhibitors from Duranta repens modulate p53 signaling pathway in diabetes mellitus. Adv Tradit Med (ADTM), 2020; 19(1): 1-2.

Kumar A, Kumar S, Jain S, Kumar P, Goyal R. Study of binding of pyridoacridine alkaloids on topoisomerase II using in silico tools. Med Chem Res, 2013; 22(11): 5431-41.

Lombardi VRM, Carrera I, Cacabelos R. In vitro screening for cytotoxic activity of herbal extracts. Evid-Based Compl Alt Med, 2017; 2017:1-8.

Lu JJ, Bao JL, Chen XP, Huang M, Wang YT. Alkaloids isolated from natural herbs as the anticancer agents. Evid Based Complement Alternat Med, 2012; 2012:485042.

Marahel S, Sharanaiah U. Anti-inflammatory and antinociceptive effect of Pachygone ovata leaves. Pharm Biol, 2016; 54(12):3046-54.

Mc Laughlin J, Rogers LL. The use of biological assays to evaluate botanicals. Drug Inf J, 1998; 32:513-24.

Meyer BN, Ferrigni JE, Putnam JE, Jacobson LB, Nicholas DE, McLaughlin JL. Brine shrimp: a convenient general bioassay for active plant constituents. Planta Med, 2005; 45:31-4.

Nainwal LM, Parida P, Das A, Bairy PS. Design and docking of novel series of hybrid xanthones as anticancer agent to target human DNA topoisomerase 2-alpha. Bangladesh J Pharmacol, 2014; 9:208-17. 
Petrovska, BB. Historical review of medicinal plants' usage. Pharmacogn Rev, 2012; 6(11):1-5.

Pimentel Montanher AB, Pizzolatti MG, Costa Brighente IM. An application of the brine shrimp bioassay for general screening of brazilian medicinal plants. Acta Farm. Bonaerense, 2002; 21(3):175-8.

Rayburn ER, Ezell SJ, Zhang R. Anti-inflammatory agents for cancer therapy. Mol Cell Pharmacol, 2009;1(1):29-43.

Rosales-Hernandez MC, Bermúdez-Lugo J, Garcia J, TrujilloFerrara J, Correa-Basurto J. Molecular modeling applied to anticancer drug development. Anticancer Agents Med Chem, 2009; 9(2):230-8.

Shirin M, Behrouz JG, Umesha S. Pharmacognostic, physicochemical and phytochemical evaluation of Pachygone ovata (poir.) Miers ex hook. f. et Thoms leaf. Int J Pharm Bio Sci, 2014; 5(4):39-53.

Sivakumar D, Richa T, Rajesh S, Gorai B, Sivaraman T. In silico methods for designing antagonists to anti-apoptotic members of bcl-2 family proteins. Mini-Rev Med Chem, 2010; 12(11):1144-53.

Suresh HM, Shivakumar B, Shivakumar SI. Cytotoxicity of aporphine alkaloids from the roots of Annona reticulata on human cancer cell lines. Int. J. Plant Res, 2012; 2(3):57-60.
WHO 2020; Avaliable via https://www.who.int/health-topics/ cancer\#tab=tab_1 (Accessed 20 Jan 2020)

Yoshikawa T, Naito Y. What is oxidative stress. Japan Med Assoc J, 2002; 45(7): 271-6.

Zhanga P, Lia XM, Liua H, Lia X, Wanga BG. Two new alkaloids from Penicillium oxalicum EN-201, an endophytic fungus derived from the marine mangrove plant Rhizophora stylosa. Phytochem Lett, 2015; 13: $160-3$.

\section{How to cite this article:}

Hullatti KK, Rodrigues J, Khanal P. In silico and in vitro cytotoxicity profile of hydroalcoholic extract/fraction(s) of Pachygone ovata. J Appl Pharm Sci, 2020; 10(05): 135-141. 